\title{
The Relationship between Financial Accounting and Tax Accounting and Its Coordination Analysis
}

\author{
Yan Chen \\ Yunnan University of Bussiness Management \\ 476372317@qq.com
}

Keywords: financial accounting; tax accounting; relationship analysis; coordination research

\begin{abstract}
With the continuous development of reform and opening-up, the trend of economic globalization has been further strengthened, which has put forward higher realistic requirements for financial accounting and tax accounting in China. Accounting standards are an important guide for financial accounting. Tax rules are the basic orientation of tax accounting. The accounting principles and regulations of tax laws need to be based on tax laws. Although the accounting principles and regulations of tax accounting are not as fair and clear as financial accounting, the use of tax accounting as an accounting method in accounting is often stronger than financial accounting in terms of rigidity and hardness. This paper mainly discusses and analyzes the relationship between financial accounting and tax accounting and its coordination, in order to better promote the coordinated development between the two.
\end{abstract}

With the gradual development of China's market economy, China's accounting system and taxation system are constantly improving, and thus more and more standardized and rationalized. Based on the continuous development of the economic society, the society has a deeper understanding of the relationship between financial accounting and tax accounting [1]. There is a corresponding difference between financial accounting and tax accounting. In the specific work of financial accounting and tax accounting, managers need to clearly distinguish the relationship between the two, which can promote the smooth development of accounting work and effectively improve the accounting management level. Thereby providing more accurate and effective accounting information for the country, and thus promoting the vigorous development of China's market economy.

\section{The link between financial accounting and tax accounting}

\subsection{Financial accounting is the basis of tax accounting}

There is often a close relationship between financial accounting and tax accounting. The tax accounting work has strong rigor. The tax accounting work needs to use financial accounting information as an important reference, and then carry out the accounting and supervision of taxpayers' economic activities on the basis of financial accounting information, so that the 
accounting management work is more standardized and scientific. However, financial accounting and tax accounting are often prone to corresponding time differences in specific operations. This requires that in the process of actually carrying out financial processing work, the staff must be effectively carried out in accordance with the relevant tax laws, which can better promote the vigorous development of China's market economy.

\subsection{The financial report reflects the coordination between the two}

The financial report can effectively reflect the relationship between financial accounting and tax accounting, which requires us to effectively coordinate the relationship between the two in the process of financial accounting and tax accounting. This will enable the relevant management objectives to be better realized and provide an important guarantee for the development of enterprises and the market economy. In general, the final coordination of financial accounting and tax accounting often requires financial reporting to reflect. Subject to tax accounting, financial accounting must comply with the corresponding tax accounting regulations in the specific work process [3]. By comparing their own liabilities and assets, the company can fully clarify the difference between the tax base and the book value. By using the income tax generated by this difference, the temporary difference between accounting profit and corporate income tax can be accurately recorded.

\section{The difference between financial accounting and tax accounting}

\subsection{Different accounting objects}

The specific accounting objects of financial accounting are usually all economic matters of enterprises measured by currency. Financial accounting can accurately reflect the financial status of enterprises, and reflect the production and operation status of enterprises and the changes of funds. Regardless of whether it involves taxation or how much is involved, in order to fully meet the target needs of corporate creditors, China's macro management, investors and business managers, it is necessary to incorporate the investment, turnover, circulation and exit of corporate funds into financial accounting[4]. However, due to the corresponding differences between the accounting scope of tax accounting and the accounting scope of financial accounting, tax accounting often involves tax revenue, income distribution, tax returns, tax payment, tax reduction, cost and capital pricing, etc. Which is related to tax. At the same time, the accounting of tax accounting is the type of financial activity such as tax payment, reimbursement, formation and calculation caused by taxation.

\subsection{Different accounting objectives}

In the specific accounting process, tax accounting often needs to take the tax law as an important work reference, and effectively achieve the effect of reducing compliance costs by implementing correct taxation, taxation, and tax refunds. In order to help tax users make reasonable and scientific tax decisions, they can provide the relevant accounting information to the tax account users, so that tax account users can maximize tax revenue by this way. The main objective of financial accounting is to calculate and record the economic business of all enterprises, and then reasonably prepare the corresponding schedules, income statements, capital flow statements, and balance sheets [5]. This not only provides relevant accounting information such as cash flow, financial status and production and operation results of the enterprise to financial report users, but also effectively reflects the specific performance of the company's management's fiduciary responsibility, and thus assists 
financial reporting users to make reasonable science, economic decision-making, thus laying a good foundation for the healthy development of enterprises.[6]

\section{Coordination of financial accounting and tax accounting measures}

\subsection{Reduce policy differences between the two}

In the past financial management of our country, there is a phenomenon of rigid financial management system and excessive financial management, which affects the further expansion of the production scale of enterprises. With the continuous development of China's market economy, China's financial system and taxation system have undergone many changes and developments, especially after the issuance of the "General Principles of Corporate Finance", the policy differences between financial accounting and tax accounting began to gradually narrow, and the coordination between financial accounting and tax accounting was strengthened. In the process of institutional reform and innovation in the future, we need to further coordinate the relationship between the two, effectively reduce the policy differences between them, and avoid the situation of inconsistency in the past, and thus ensure that the taxable income of enterprises can be consistent with the accounting income. As far as China's current market economy development is concerned, narrowing the policy differences between financial accounting and tax accounting can ensure the smooth development of corporate accounting management, but because there are still long-term differences between the two, Some differences still cannot be eliminated in a short time. For example, corporate illegal expenditures or illegal operations are subject to administrative fines and judicial fines from government departments. When conducting financial accounting work, subjects such as costs, expenses, and losses can be accounted for. However, according to the relevant provisions of the tax law, such expenditures cannot be effectively applied to the tax credit process. This directly reflects the nature of the tax law to collect tax revenue for the state with tax interests as the goal.

\subsection{Realize the convergence of the two}

Financial accounting and tax accounting are driven by the optimization of resource allocation benefits and the objective theoretical basis, and it is easy to gradually become assimilated. From the current situation of China's tax collection and management work and accounting work, the development of convergence between financial accounting and tax accounting is becoming more and more obvious. The first is the coordinated development of the accounting system and the tax laws and regulations, which gradually began to show the form of assimilation between the two. Whether in the real world or in the theoretical world, the enterprise agrees with the authority and effectiveness of accounting standards and accounting systems formulated by the Ministry of Finance. The Ministry of Finance also has the responsibility to formulate China's tax laws and regulations, which can lay a good realistic foundation for the convergence of China's accounting system and tax regulations. With the gradual strengthening of the coordination of laws and regulations in China, China's financial accounting and tax accounting will also develop in the direction of convergence and coordination. Secondly, the planning activities of Chinese enterprises will also affect the development of financial accounting and tax accounting. If the income and expenses of enterprises are certain, the tax payable by enterprises and the profits after tax will be an inverse relationship. Therefore, in order to effectively reduce their own tax burden, enterprises need to achieve reasonable tax avoidance through tax planning, which promotes the coordinated development of China's tax policy and accounting system to a certain extent. 


\section{Conclusion}

All in all, although there are corresponding differences between China's financial accounting and tax accounting, as long as the relevant management personnel effectively distinguish the relationship between financial accounting and tax accounting, they can form a deeper understanding of the two, thus making the financial Accounting and tax accounting can be carried out in a reasonable and orderly manner, laying a good foundation for improving the quality of financial accounting and tax accounting. By in-depth analysis of the differences between the two, we can find suitable entry points to coordinate the relationship between the two, while protecting the healthy development of Chinese enterprises, it also increases China's fiscal revenue, and then drives the vigorous development of China's market economy.

\section{References}

[1] Xin Lianjie. The Relationship between Financial Accounting and Tax Accounting and Its Coordination [J]. Enterprise Reform and Management, 2014 (06).

[2] Zhao Yun. The relationship between financial accounting and tax accounting and its coordination [J]. Modern Marketing (late issue), 2014 (12).

[3] Ge Fengyun. Research on the Relationship between Financial Accounting and Tax Accounting [J]. Economic and Trade Practice, 2015 (06).

[4] Meng Qingxian. The relationship between financial accounting and tax accounting [J]. Finance and Economics (Academic Edition), 2015 (21).

[5] Jiang Yonghuan, Jiang Yongcheng. Analysis of the relationship between financial accounting and tax accounting [J]. China Collective Economy, 2011 (16).

[6] Zhang Yongxiang. Comparison of fair value of financial accounting and tax accounting and its mutual reference analysis [J]. Manager, 2011 (23).

[7] Nie Shunjiang. On the Establishment of Tax Accounting and Its Relationship with Financial Accounting [J]. Journal of Yunnan University of Finance and Economics, 2013 (03). 